\title{
Revisit to Policy Formulation for Climate-Smart Agriculture in India
}

\author{
Bibhu Kaibalya manik
}

\begin{abstract}
Potential influence of water stress, climate change, erosion of fertility, unorganized agro-financing practices in agricultural-yields espoused with incongruity in regulating and developing the credible distribution mechanism for the resilience of computable equilibrium in the supply chain have warranted the continuing negative economic implications relating to agricultural production-patterns as well as ensuring food security of the country. An authoritative introspection for the sustainability of agro-economic policy in consistence with the increasing population becomes the cry of the hour of the country. Sensitivity-variance of different crops to warming though confines the scopes and preferences of territoriality of productivity however, the complexity of impact of climate-change on agricultural productivity necessitates the appraisal and interrelations of physical, economic and social factors as well changing ecological imbalances. The attempt to bring structural reforms in the farming practices in weather variability context in the country requires financial support for the marginal and small-scale farmers as farming practices are predominantly adapted to local climates. The global character of atmospheric circulation and the impact of ecological and climate-changes encourage combined use of climate, crop, and economic models for sustaining growth of supply chain to market. In addition, the increasing deterioration of agricultural production due to the eventuality of climate-change and eventual ecological imbalance considerably would affect the trade balance of the country for the legislative mandate of food security. To transform the progressive move of LPG (Liberalization, Privatization and Globalization) into secured and sustainable agro-economy to save our planet from the ravages of climate change, a comprehensive schematic approach involves configuration of legal and policy tools containing thereof: a) 'spillover costs' of agricultural productivity due to increased ecological and climate changes; $b$ ) coherent assessment of the modalities of agriculture to harmonize the present-day water-stressed; c) coherent financing mechanism for the farmers, in particular the small-scale and marginal ones who are not only being affected disproportionately rather the changes warrant them to be displaced internally. The present discussion reviews two prime factors: viz; a) Effects of Climate-Change upon agro-economy of the country; and b) Attenuation of Agro-financing measures in the regulatory mechanism for regulating and developing the vibrant supply chain to the market.
\end{abstract}

Keywords: Climate change, Agro-economy, Supply chain, Sustainable, LPG

\section{INTRODUCTION}

Most of the world's poor people earn their living from agriculture, so if we knew the economics of agriculture, we would know much of the economics of being poor. - Theodore Schultz'

Impending election made the government much proactive to address the farmers' distress as top priority manifests that a) Indian agro-sector has secured the berth in the spectrum of political economy of the country; and b) agriculture becomes instrumental to reap the political dividends ${ }^{1}$ which in turn impose tax burden upon the taxpayers due to deficiency of State's Gross State Domestic Product. Such write-offs of the NPAs by the Banks or proposed DBT (Direct Benefit Transfer) can neither be the sustainable solution of the poor financial lives of the small or marginal farmers of the country nor increase agricultural productivity and in no way contributes even the transformation of agricultural pattern or developmental goals concomitant with changing climate rather escalation of fiscal deficit of the country. The diversion of land utilization triggered in view of infrastructural and other sustainable developmental goals vis-à-vis the increasing number of marginal and small farmers' holdings (Fig:1) along with the operated areas for agriculture (Fig:2) corresponding to forest preservation mission due climate change (Fig:3) ensues serious constraints regarding achievement of food security of the country. In addition, gradual decline of working forces has made the Agriculture sector (Fig 4) more labourintensive.

Figure: 1

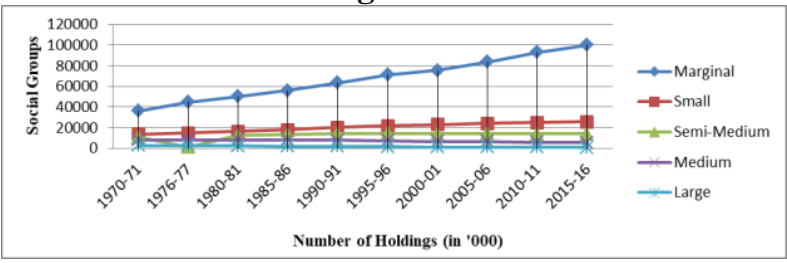

(Source: All India Report on Number and Area of Operational Holdings, Agriculture Census Division, Ministry of Agriculture \& Farmers Welfare, Govt. of India, 2018)

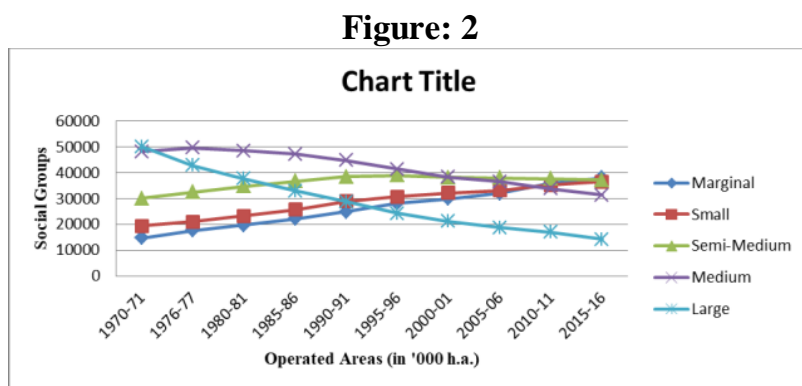

(Source: All India Report on Number and Area of Operational Holdings, Agriculture Census Division, Ministry of Agriculture \& Farmers Welfare, Govt. of India, 2018) 
Figure: 3

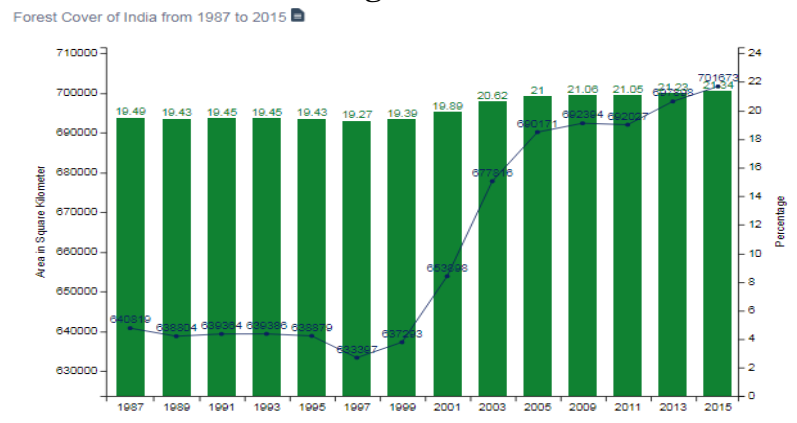

(Source:

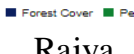

Sabha:

available at https://community.data.gov.in/forest-cover-of-india-from1987-to-2015/)

Figure: 4

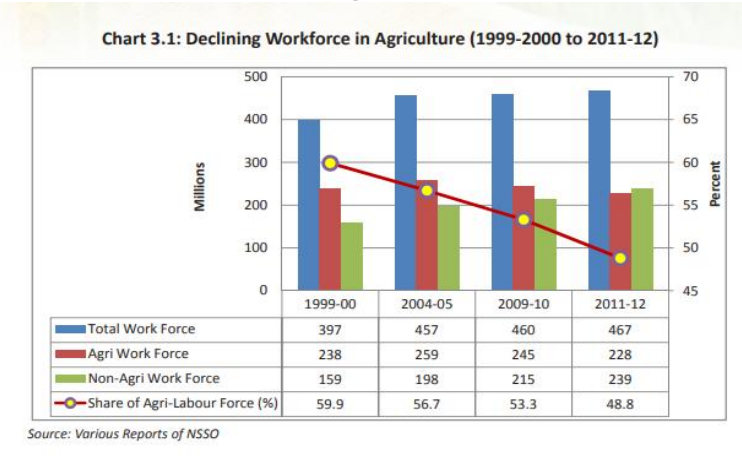

Agriculture is considered to be most climate sensitive human activities ${ }^{2}$ also the trans-boundary nature of atmospheric concentrations has undeviating relation and impact upon the agricultural productivity. The complex composition and inter-relations of atmosphere-ocean-land components in the climate system has combination effect in productivity losses. Sustainability of Natural Ecosystem, Economic Growth and other Social-Developmental programmes with the increasing population has triggered the agricultural-policy leaders to audit the opportunities and options relating to agricultural production in the context of Climate-change constraints and food security conjointly. The global settlement on 'Sustainable Development' from the economic-perspective in view of the impact of Climatechange upon the agricultural productivity echoes the challenges; firstly, to the legal system in composing the harmoniously balanced and minimization of conflicts between the Market Demand ${ }^{3}$ and Right to Pollute ${ }^{4}$. The pursuit of the global practice of 'Carbon credit' or say 'Carbon border tax ${ }^{5}$ by the manufacturers in producing high - yielding agro - tools and ancillaries should be considered in the policy framework of 'sustainable development' for the myriad and marginal farmers in India though Jaivik Kheti ${ }^{6}$ however, this experimental journey at the pilot stage or within localized area would again require the test of time and self-sustainability and the wrath of climate-change would affect both the agricultural productivity and food security unless the experiment be completed in a time-bound manner with market-oriented perspective. Post-Independent policy designing relating to agricultural sector of the country had had the predisposition to promote social justice hence, social welfare was incentivized by subsidies in 'commandcontrol' economic model, however, the on-going officially attested mission of 'liberalized economy' and 'sustainable development' model the focus has been swiveled to sustaining growth rate and 'add-on' marginal output to perpetuate the per-capita growth rate and availability of food-grains to harmonize the increasing population. Secondly, the ill-assorted concoction of market structure, market conduct and market performance, disintegrated agricultural markets, inter-regional movement restrictions, etc. are the stumbling blocks for the creation of a National Market for the agricultural commodities. The multiple layers of unaccounted and unlicensed but organized intermediaries have already formed the cartel and been creating artificial glut conditions to pay low prices and pauperize the small and marginal farmers. Market can play an effective role if the niceties among the structure, conduct and performances be ensured with open policy initiatives provided the market barriers developed by said intermediaries could effectively be addressed. The schemes like, $\mathrm{KCCs}^{7}$ to provide relevant material information to the farmers, mKisan $^{8}$ to provide symmetric information to the farmers, ATMA $^{9}$ for evaluating the physical and financial progress, $\mathrm{eNam}^{10}$ for transparent sale transactions and price discovery in regulated markets, etc., although have been introduced in the developmental policy however, the deficiency in building the infrastructure required to support and supplant to work out such wide spectrum of development has restrained the implementation of the policy in full-fledged. Thirdly, the cooperative, coordinated and responsible approaches of the regional institutional and non-institutional actors in multiparty democratic governance pattern is of high-priority in promoting the sector-specific National Policy tools, especially, the "agriculture" ${ }^{11}$ to operationalize beyond the trajectory of socio-political and politico-economic priorities. The new paradigm of participatory model of governance to endorse 'sustainable growth' requires also a comfortable socio-political habituation within the purview of such policy otherwise, the institutional structure in endorsing its resource distribution mechanism would evolve the complex outcomes and the consequential economic effect may encourage: a) monopolistic behaviours of the Industrial producers for the retention of considerable part of potential profits; b) the social waste of natural resources; and c) frustration in the market relating to value-bargaining between sellers and buyers ${ }^{12}$. Till date the investment from external financing is allowed on the sectors relating to agricultural services and tools but not to foster the agricultural productivity ${ }^{13}$. NAPCC ${ }^{14}$ has already set the paradigm of normative monitoring mechanism for Sustainable Agriculture $^{15}$ through relevant Ministries however, one regulatory body is essential. The possible alignment of approaches between 'traditional constraint' and 'global aspiration' may be homogenized by the use of market-based 'price' and 'trade' policy by the strength of efficient normative imperatives in agricultural farming as well because kleptocracy for last seven decades has already 
weakened implementation mechanism and has fostered waste of financial resources through the ill modes of sectoral-distribution of subsidies by the ends of the State ${ }^{16}$. For example, to boost the agricultural sector i) Minimum Support Prices (MSP) of at least 50\% higher than cost of cultivation for major crops (both kharif and rabi); ii) GrAM (Grameen Agricultural Markets) initiative to develop and integrate the rural unorganized markets and incentivize the primary producers; iii) Kisan Credit Cards (KC); etc though announced however, hardly any one such scheme has surfaced to reality. The internal form of distribution of financial resources for the upliftment of the small and marginal farmers has failed to establish any visible capital formation whereas providing an income-support marketinfrastructure with target-oriented subsidy benefits may stimulate the driving forces. The Commission for Agricultural Costs and Prices concluded with similar recommendation, "that scheme of interest subvention should be extended to investment credit to improve capital formation in agriculture"17. Fourthly, the high cost of purchase and maintenance of high-end eco-friendly technology and skill $^{18}$, along with the irrigation costs, electricity, fertilizers, pesticides within the seasonal timeline to collate the 'global aspiration' within the structures of the agricultural pattern through the small and marginal farmers requires efficient financial mechanism for the allocation pattern $^{19}$ and support for mitigation ${ }^{20}$. Lastly, the increasing population and sharp decline in cultivable land per person due to growing infrastructure development not only prompted the issue of food security rather the unquestionable emphasis upon the escalation of agroproduces through the strict control of anthropogenic approach through the governmental and non-governmental actors across different geographical-regions to uphold the universal principle of bottom-up approach for achieving global commitment on Climate-change ${ }^{21}$. The final negotiation erstwhile in adapting 'bottom-up' regime in $\mathrm{COP} 23^{22}$ on Climate-change with international cooperation and contribution strongly influence for policy choices to design time-bound Action Plan to arrive at meaningful outcomes in the landscape of national development. The eventuality of Bonn Conference confined to prioritize three important areas in the landscape of Climate-change for restoration process, viz;: a) Present status; b) Targeted or Prospective Status and c) Objectives to achieve prioritizing the political commitment and collective-action of every nation with the pledge to ensure the fulfillment of pre-2020 implementation. The potential transformative effect of global-warming and environmental changes, though unpredictable, however the increasing disastrous and impending damage upon agriculture-productivity are quite enormous and complex.

The complexity of impact of climate-change on agricultural productivity necessitates the appraisal and interrelations of physical, economic and social factors as well changing ecological imbalances. The impact of Climate-change although has invoked the future risk in agro-productivity and supply chain, however, the metricvariants, like, meteorological, hydrological, plant physiological quantities or pests and diseases, etc. have been kept outside the purview of this discussion except where it is reasonably required for the purpose of reconfiguration of the agro-policy in view of Climate-change and the agrofinancial mechanism to ensure the vibrant supply chain and food security. Sensitivity-variance of different crops to warming is one decisive factor that confines the scopes and preferences of territoriality of productivity hence needed to be accounted in the policy design.

The initial cost of ecosystem-restoration is admittedly high and for the successful regeneration in view of fastforward march of Climate-change and its impact upon the productivity-growth adjures the need for adoption of novel technologies to contribute both the agricultural productivity and harmonious restorative operation of ecosystem. Developing a paradigm on Climate-change essentially calls for the appreciation of commonality, contrasts and interlinks of security risks, national economic interests, energy security, ecological vulnerability etc. Fact that even in LPG regime the aggregate impacts of climate change on globalscale agricultural productivity cannot be reliably quantified. In addition, the disbandment of agricultural tariffs and subsidies in the Doha round of WTO negotiations has caused much economic hardship to the food-importing developing countries ${ }^{23}$. And third world countries that are typically located in warmer, lower latitudes, and major economy is agriculture, like India, are strongly influenced to vulnerable variability in its productivity besides the legislative mandate of food security. Apart from the schematized programmes of internal financing ${ }^{24}$ for the leverage of agricultural sector by the State a target-based comprehensive inclusive national policy requires to be designed to accommodate the private players to evolve out a National Market to ensure competitiveness and market efficiency for the sustaining economic growth and food sovereignty. Such private investment in agricultural sector would provide new opportunities of economic-activities, promote sustainability and reducing poverty and hunger. External financing to agricultural sector can be the effective contributory for the sustaining growth as well as the removal of heavy subsidized financial contribution to this sector and reduce the government's debt to country's GDP.

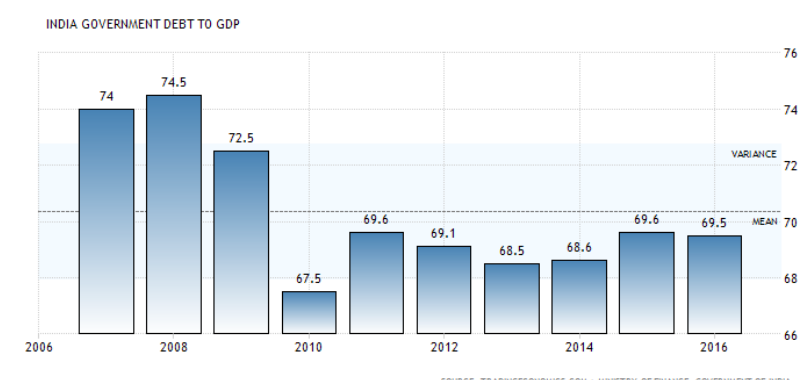

Figure: 5: *Source: India Government Debt to GDP 1991-2017 ${ }^{25}$

The following chart (Fig. 2) ${ }^{26}$ provides substantial report on: a) increasing population but decreasing percentage of employment in the agricultural sector; b) weak enforcement of normative 
imperatives in the agricultural sector for emission control of GHGs; c) unimpressive return of the amount of investment being made through internal mode of financial allocation of resources; d) increasing value of food production and decrease in GVA in agriculture-sector; e) growing demand of imports(Figure 3$)^{27}$; and f) the gradual upturn of the emission of GHG.

\begin{tabular}{|c|c|c|c|}
\hline Particulars & 1990 & 2000 & 2014 \\
\hline Population, total (mln) & 868.9 & 1042.3 & 1267.4 \\
\hline Population, rural (mln) & 646.9 & 753.9 & 857.1 \\
\hline $\begin{array}{l}\text { Govt expenditure on ag (\% } \\
\text { total outlays) }\end{array}$ & & 4.1 & 6.5 \\
\hline Area harvested (mln ha) & 226 & 299 & 341 \\
\hline Cropping intensity ratio & 1.2 & 1.7 & \\
\hline $\begin{array}{l}\text { Water resources }(1000 \mathrm{~m} 3 \\
\text { /person/year) }\end{array}$ & 2 & 2 & 2 \\
\hline $\begin{array}{l}\text { Area equipped for irrigation } \\
\text { (1000ha) }\end{array}$ & & & 66700 \\
\hline $\begin{array}{l}\text { Area irrigated (\% area } \\
\text { equipped for irrigation) }\end{array}$ & & & 93.9 \\
\hline $\begin{array}{l}\text { Employment in agriculture } \\
(\%)\end{array}$ & & 59.9 & 47.2 \\
\hline $\begin{array}{l}\text { Employment in agriculture, } \\
\text { female }(\%)\end{array}$ & & 74.8 & 59.8 \\
\hline $\begin{array}{l}\text { Fertilizers, Nitrogen (kg of } \\
\text { nutrients per ha) }\end{array}$ & & 69.3 & 107.9 \\
\hline $\begin{array}{l}\text { Fertilizers, Phosphate (kg of } \\
\text { nutrients per ha) }\end{array}$ & & 25.9 & 43.1 \\
\hline $\begin{array}{l}\text { Fertilizers, Potash (kg } \\
\text { nutrients per ha) }\end{array}$ & & 10 & 12.7 \\
\hline $\begin{array}{l}\text { Energy consumption, power } \\
\text { irrigation ( } \mathrm{mln} \mathbf{k W h})\end{array}$ & 2 & 1859 & 1881 \\
\hline $\begin{array}{l}\text { Agr value added per worker } \\
\text { (constant US\$) }\end{array}$ & 459 & 528 & 689 \\
\hline \multicolumn{4}{|l|}{ Hunger Dimensions } \\
\hline $\begin{array}{l}\text { Dietary energy supply } \\
\text { (kcal/pc/day) }\end{array}$ & 2279 & 2370 & 2469 \\
\hline $\begin{array}{l}\text { Average dietary energy } \\
\text { supply adequacy }(\%)\end{array}$ & 105 & 107 & 108 \\
\hline $\begin{array}{l}\text { Dietary en supp, } \\
\text { cereals/roots/tubers (\%) }\end{array}$ & 66 & 63 & 59 \\
\hline $\begin{array}{l}\text { Prevalence of } \\
\text { undernourishment }(\%)\end{array}$ & 23.7 & 17 & 15.2 \\
\hline GDP per capita (US\$, PPP) & 1777 & 2548 & 5244 \\
\hline $\begin{array}{l}\text { Domestic food price } \\
\text { volatility (index) }\end{array}$ & & 3.9 & 6.4 \\
\hline $\begin{array}{l}\text { Cereal import dependency } \\
\text { ration }(\%)\end{array}$ & -0.2 & -1.4 & -3.1 \\
\hline $\begin{array}{l}\text { Underweight, children } \\
\text { under-5 }(\%)\end{array}$ & 50.7 & 44.4 & 43.5 \\
\hline $\begin{array}{l}\text { Improved water source (\% } \\
\text { pop) }\end{array}$ & 70.3 & 80.6 & 92.6 \\
\hline \multicolumn{4}{|l|}{ Food Supply } \\
\hline $\begin{array}{l}\text { Food production value, } \\
(2004-06 \mathrm{mln} \mid \$)\end{array}$ & 119804 & 156265 & 236540 \\
\hline $\begin{array}{l}\text { Agriculture, value added (\% } \\
\text { GDP) }\end{array}$ & 29 & 23 & 17 \\
\hline Food exports (mln US\$) & 1013 & 2826 & 20835 \\
\hline Food Imports (mln US\$) & 758 & 2062 & 16523 \\
\hline \multicolumn{4}{|l|}{$\begin{array}{l}\text { Production indices (2004- } \\
06=100)\end{array}$} \\
\hline Net Food & 70 & 92 & 139 \\
\hline
\end{tabular}

\begin{tabular}{|c|c|c|c|}
\hline Net Crops & 73 & 92 & 142 \\
\hline Cereals & 82 & 98 & 123 \\
\hline Vegetable oils & 78 & 81 & 134 \\
\hline Roots and tubers & 55 & 88 & 152 \\
\hline Fruit and vegetables & 61 & 89 & 163 \\
\hline Sugar & 90 & 119 & 136 \\
\hline Livestock & 61 & 85 & 135 \\
\hline Milk & 56 & 83 & 141 \\
\hline Meat & 77 & 90 & 117 \\
\hline Fish & 57 & 85 & 139 \\
\hline \multicolumn{4}{|l|}{ Net trade (mln US\$) } \\
\hline Cereals & 191 & 803 & 9154 \\
\hline Fruit and Vegetables & -34 & 434 & -1551 \\
\hline Meat & 79 & 325 & 3145 \\
\hline Dairy products & -1 & 12 & 56 \\
\hline Fish & 467 & 1402 & 3326 \\
\hline \multicolumn{4}{|l|}{ Environment } \\
\hline Forest area (\%) & 22 & 22 & 23 \\
\hline $\begin{array}{l}\text { Renewable water res } \\
\text { withdrawn ( } \% \text { of total) }\end{array}$ & & & 90 \\
\hline $\begin{array}{l}\text { Terrestrial protect areas (\% } \\
\text { total land area) }\end{array}$ & 5 & 5 & 5 \\
\hline $\begin{array}{l}\text { Organic area (\% total } \\
\text { agricultural area) }\end{array}$ & & & 0 \\
\hline $\begin{array}{l}\text { Water withdrawal by } \\
\text { agriculture (\% of total) }\end{array}$ & & & 90 \\
\hline $\begin{array}{l}\text { Biofuel production } \\
\text { (thousand kt of oil eq.) }\end{array}$ & 304 & 510 & 2505 \\
\hline \multicolumn{4}{|l|}{$\begin{array}{l}\text { Wood pellet prod. }(1000 \\
\text { tonnes })\end{array}$} \\
\hline $\begin{array}{l}\text { Net GHG emissions from } \\
\text { AFOLU (CO2 eq, Mt) }\end{array}$ & 476 & 505 & 532 \\
\hline
\end{tabular}

*Indices of agricultural production for each year in comparison with the base period of 2004-2006 and deductions of quantities used as seed and feed from the sum of price-weighted quantities of production to avoid double counting.

Figure: 6

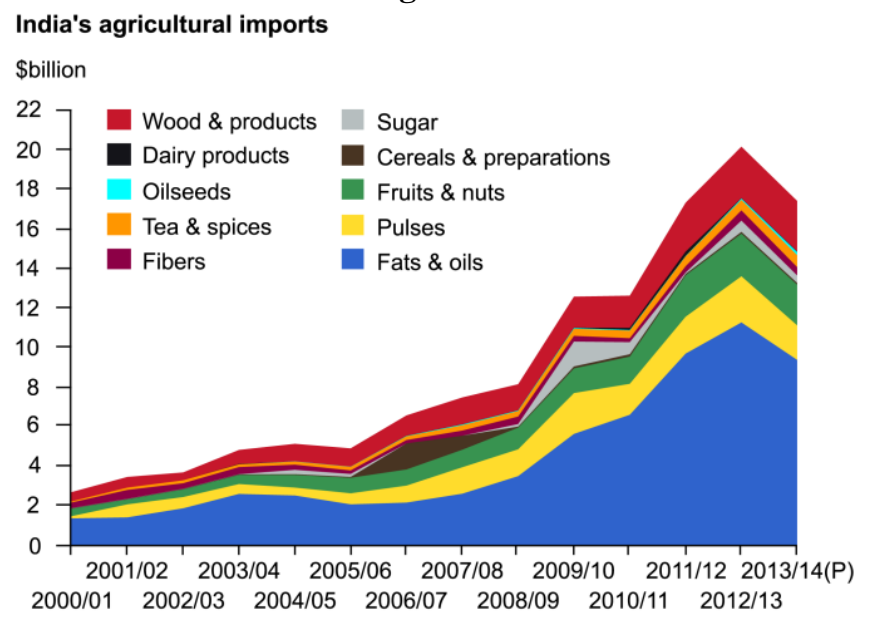

Source: USDA, Economic Research Service using Government of India, Directorate of Commercial Intelligence \& Statistics, Ministry of Commerce data. $(\mathrm{P})=$ Provisional. 


\section{II.}

The symbiotic relation around for millennia, between the informal Moneylenders and Farmers relating to agrofinancing and supply-chain of agricultural productivity in India historically visible to have been endogenized with its complex structures. The organizational structure plays an effective role in enabling the supply of excess produce in the market because the mainstay of majority farmers' confidence in contributing the supply chain provided it is organized and perfectly regulated by the normative imperatives. The market efficiency or performance in the context of trade liberalization is conditioned by: a) market integration; b) the institutional support in transparency and timely-dissemination of market information regarding price signals (including volatility and predictions) to the producers (sellers) and transaction costs; c) risk mitigation; d) effective mobilization of potential physical flows of the commodities. The organizational structure of agricultural produces permeated in India are like, Producers' Cooperative for marketing ${ }^{28}$, governmental agencies ${ }^{29}$, traditional unregulated Markets, and the like, however, to improve agricultural marketing a model central legislation ${ }^{30}$ was provided as guideline to all States for the purpose of legislating upon it so that the integration and interlink between the domestic markets with the international market could be formalized. In order to actuate such guidelines presence of governmental agencies relating to the advantage and availability of grading facilities of the produces, storage capacities and market yards facilities were quintessential. The organized but unlicensed and unaccounted intermediaries by making such arrangements have interspaced between the actual sellers and buyers and in connivance at each other have been maintaining appreciating the higher transaction costs in the domestic markets and the malpractices thereof.

The ethos of 'trade-based' agricultural productivity during colonial regime in India made to abhor the private participation in the agricultural sector since independence however, contemporaneous liberalized economy requires the strategic alignment of public and private funds for the purpose of distribution and capitalization of financial resources through various schematic programmes to agricultural sector, insurance products for agro-productivity and additionally felt-need is that the availability of those financial services could mitigate the need-based demands of the farmers for fostering the market demands. Growing concentration of financial resources in the private funds in liberalized economy can be systematized with the conventional measures of financing through formal financial institutions in agricultural sector is the particular enclosure wherein the priority of enhanced productivity and food sovereignty is confined. The strategic and planned combination of external and internal forms of financing in the agricultural sector would reduce the allocation of public expenditure to agriculture as well as would augment the economic value of farming outputs, opportunity of portfolio diversification to the private market players, efficient market forces and productivity growth in agricultural sector.

For example, MSP insurance policy ${ }^{31}$ was introduced during 'command-control' economic model where government intervention was significant in price-parity

particularly in terms of national and trans-national trade. Thus, heavy subsidy through the internal form of financing has lowered down the price performance of the farm outputs. In contemporaneous 'liberalized economy' the strategic programme of external financing through private players at fixed lower interest rate with the combination of insurance coverage for the affected agricultural produce by State would empower and motivate the small and marginal farmers to take the advantage of potential profitability in the competitive system driven by consumer demand as well dominance of value chains of supply could be ensured. The pre-eminent role of unaccounted intermediaries in the supply chain in the agro-product market is the reasons for the higher value and higher transaction cost, wide gap between WPI and CPI in the domestic market. The oddity is that financial advancement by financial institute in agricultural sector cannot be considered to be $\mathrm{NPA}^{32}$ therefore opportunities of private participation relating to investment and effective risk mitigation in agricultural sector in India becomes limited except those intermediaries intricately associated in the supply chain of the agricultural produces, e.g., the commodity traders, distributors and moneylenders, etc. which in turn, appreciates the transaction costs and depreciates the Minimum Support Price mechanism. Fact that though through land reforms since independence has ensured the statutory tenurial protection of marginal and small farmers has been ensured to remove the rigid concentration of control in agricultural sector, however, the functional and multiplicative-contributory role of the farmers of smallholdings cannot be ignored in the valued supply chains to ensure food sovereignty of the country. Thus the specific challenges in the providing protective opportunities for delivering better flow of capital, risk assessment and management and lowering transaction costs of such majority farmers in India. The schematic approach of PMJDY has already set up the platform for easy distribution of financial resources under social welfare schemes to the mass myriad of the country.

To meet the end in today's fast moving liberalized economy in the agriculture sector in particular in developing countries require a) capital formation in the sector for selfsufficiency; b) risk reduction and/or mitigation; c) market efficiency; and above all d) effective normative imperatives to uphold social equity. And again investment of private capital and insurance as well for the small and marginal farmers is possible only when the investor(s) as well as insurer(s) on completion of the cost-benefit analysis including the creditworthiness of the targeted groups concludes about the presence of substantial drivers in the context-specific sector with valuable surplus.

Self-sufficiency or Capital formation: The DBT (Direct Benefit Transfer) mode of public financing by government to the Farmers, in particular to the small and marginal farmers may be frustrated for: a) lack of background information about the median sources of income of those small and marginal farmers because the existential question of them may lead to do variety of economic activities for 
livelihood, like, non-agricultural production, or livestock, or selling labour, or small businesses, or even migrated to construction sector, etc thus, direct benefit transfer may not only be diversion of such direct benefit to some other sector rather under utilization of land resources and ultimately affecting agricultural productivity; b) the actual demand-size for financing cannot be estimated; and c) the welfare mission to alleviate the poverty of the small and marginal farmers would be frustrated. The approach to transcend the under-capitalization in agricultural sector is capital formation through strategic projection of opportunities to the private funds for selling their loan products homogenized with State-sponsored crop- insurance coverage to the individual farmers. For the empowerment of the small and marginal farmers in the country and sustaining profitability the present loan assessment model may appear like: the advancement of loan may vary with the variance of the farm products in various geographical limits of the country. Supportive instruments contain valued date for the advancement of such loans, viz; the nature and amount of land of the borrower ${ }^{33}$, the proposed farming of $\operatorname{crop}(\mathrm{s})$, the number of family or families ${ }^{34}$, etc. can provide the possible amount of produce in specific seasonal cultivation. Such loan shall be distributed through the appointed agents of the financer so that the valued data chain between the farmer and the financer could be established to narrow down the scope of loan default. The performance of individual financing through private funds (predominantly informal moneylenders) during colonial time has benchmarked: a) the utilization of the opportunities, natural resources and consequential victimization made by the private players; $b$ ) the profitable productivity in agricultural sectors; c) the efficiency and contributory roles of the small and marginal farmers in individual financing for agriculture. The constant involvement and monitoring performed by such private players in regards of every individual borrower enabled them to customize the loan amount and thus chances of default was minimal unless the productivity of the year affected due to natural disasters. It is only the 'capacity building' amongst the myriad and marginal farmers in the governance pattern that makes the difference between the external financing during colonial India and what is suggested herein in Independent India. Since the achievement of Independence to operationalize the perambulatory mandate the State has promoted the social and economic justice and even proportional equitable approach of subsidy has also been introduced however, failed to enable to promote the scale of improvement and competitiveness in this sector. The need of the hour in agricultural sector is capital formation to ensure better access to credit, markets, eco-friendly mechanization and technology, in addition to land tenure rights and equity in vibrant supply chain of agricultural produces in the integrated national market. After seven decades social equity has ascended to a remarkable height of the developmental scale but for the reasons being stated earlier, the potential contribution of sectoral productivity is not commensurate with the long-term financial contribution ${ }^{35}$ made to the sector by the State. The following figures (viz; 4 $\& 5)$ are self-explanatory to describe the gap between the

demand and supply of foods in the market and to distance to be covered to achieve the food sovereignty in the country.

Figure: 7

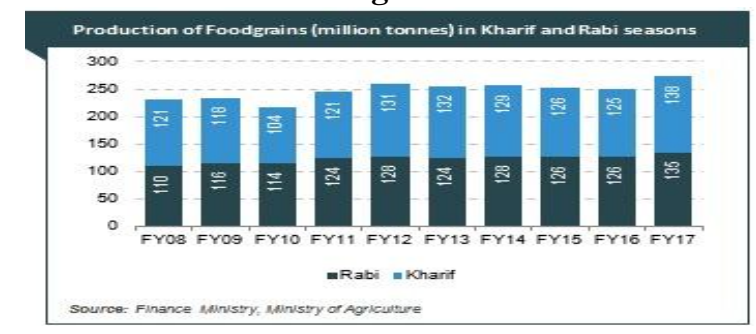

Figure: 8

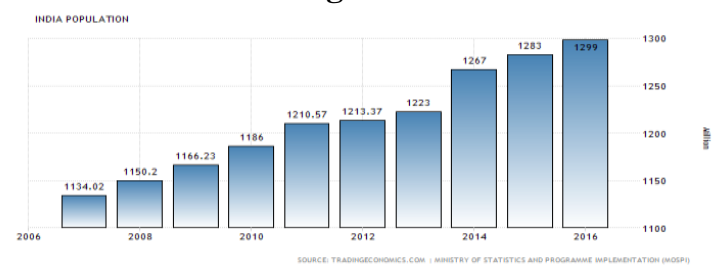

*Source: Tradingeconomics.com: Ministry of Statistics and Programme Implementation (MOSPI)

Figure 3 has clarified the market-demand and the deficiency in the supply chain of the country and Figure 2 has established the contributory role of government debt to enhance the GDP. Hence, sustaining economic growth would be a myth unless the fair returns of the investment are not being encouraged in the sectors what in the landscape of trade appears to be prospective and feasible. Lack of legal framework in enlarging individual lending models has resulted in not only the hindrance to access to the credit system rather horizontal integration of informal intermediaries to be informal moneylenders and 'market makers' and low profitability in agro sector of the country. What is suggested is in place of promoting internal value chain finance it is better to set up external value chain finance and the integration both would enhance the competitiveness and opportunities to the small and marginal farmers.

Risk Reduction or Mitigation: The manufacturing companies producing agro-chemicals, pesticides, machineries and tools, etc. may be issued with the mandate to invest the amount accrued on CSR account in the longterm regeneration process of ecosystem and climate while the Insurance companies may also be directed to invest ${ }^{36}$ in this regard so that maintaining price-parity may be allocated. Again issuance of normative mandate for utilization of a determinate portion of the CSR fund of other eligible business entities for promoting technological and skill development services to the agricultural sector other than afforestation would be one viable option. For external financing the Supply contract ${ }^{37}$ for having the access to private funds for agro-chemicals or Pledge of produce ${ }^{38}$ with put option for the purpose of purchasing the farm inputs at the right time without selling their crops at lower price may be considered to be some viable options to be insisted upon 
for providing leverage to the agro-sector and to develop and strengthen the value chains ${ }^{39}$. Contract farming, though, has already been suggested in the central APMC Model Act 2003 however the piecemeal attention to it of the respective States of the country to review and develop the suitable mechanism to its respective localities turned down the chances and opportunities of achieving food sovereignty. Besides, as suggested earlier, the loan products of the private external agencies should be strategized with the insurance coverage to be borne by the government by virtue of what the settlement of loan in the event of lowproductivity due to natural disasters or climate change could be made possible. The intervention of state mechanism in making such declaration would prevent such external agencies to set in motion the recovery mechanism. Making opportunities of individual financing through external agencies would enable to reshape the structural dimension of the existing market and practices. The expected competitiveness among the financing agencies would enable in accounting the market players and the flexibility in the norms in the financing mechanism would be beneficial to the farmers for having more choices and opportunities while accessing to credit and services.

Market Efficiency or Normative Imperatives: The bottom line of market efficiency depends primarily on the effective allocation of the resources, fair competition, fair opportunities of bargaining powers etc. so that pricing of products become the subjectivity of only demand-supply forces. Pooling of surplus products in the supply chain becomes possible once the price information (including the future price trends) is made available to the producers and in open market-economy this is possible with the intervention of statutory market regulator to maintain and promote the competitiveness. CCI - the existing market Regulator of the country may be empowered in this regard to intervene and ensure the fair competition so that the agricultural sector be strengthened by capital formation. Establishment of the link between the national and international market and dissemination of information to the farmers through the Regulator(s) would encourage the farmers towards higher yielding.

And all these can be accentuated if the normative imperatives relating to i) character; ii) capacity; iii) capital; iv) collateral; and v) conditions of such loan products be accommodated suitable to the local conditions as the regulatory tools with strict compliance mandate are designed in the policy for the legal norms are nothing but the exposition of the policy. Normative imperatives have long been established to be most important indicator to establish most viable characteristics of investment-environment for the developmental programmes of the country so that through such alternative financial mechanism higher agricultural productivity and food sovereignty could be achieved.

\section{REFERENCES}

1. Loan-waiving strategy has been adapted by some newly elected State governments, for example, Madhya Pradesh, Rajasthan, Chattisgarh, resulting in escalation of NPAs to the tune of 1.47 lakh crores of March 31, 2018. Available at https://www.indiatoday.in/india/story/farm-loan-waivercongress-bank-npas-rajasthanmadhya-pradesh-chhattisgarhfarm-crisis-1414414-2018-12-21 (last visited on Feb. 8, 2019 at 10:12 A.M.)

2. For example State of Odisha is categorized into ten agroclimatic zones based on soil structure, humidity, elevation, topography, vegetation, rainfall, etc.

3. 'Market demand' denotes the demand of the farmers, in particular financing for availing of the technologically advanced instruments, chemical fertilizers, pesticides, etc. for increasing the productivity.

4. 'Right to pollute' denotes the negative right of the Manufacturers emitting pollutants to environment, affecting indirectly the farmers' better yielding opportunities of agricultural produce.

5. Reflects of carbon costs in material prices for the carbon emissions - the key objective of European Union in Emission Trading System

6. The National Project on Organic Farming schematized in the $10^{\text {th }}$ Five-Year Planning and still continuing as pilot project.

7. Kisan Call Center

8. The SMS portal for the farmers

9. Monitoring system of Monthly Progress Report

10. National e-market platform

11. Item 14, State List, Constitution of India.

12. This is because due to the spread of the costs of carbon credit or carbon-border tax would be distributed in transaction costs for preserving the potential profits while diminution of potential values of agricultural produces due to unorganized and frayed market structure.

13. Foreign Direct Investments by Parle Agro Pvt. Ltd. in launching Frooti Fizz; Zephyr Peacock Private Equity Fund (US) investment in Utkal Tubers India Pvt. Ltd for producing high-quality mini-tubers in a tissue culture laboratory to multiply them in its own development farms through contract farming

14. National Action Plan on Climate Change (2008), Government of India

15. Id., II 4.7 at 9. It has been resolved to develop a) crop variants compatible to extreme thermal and variable moisture resistant; b) alternative cropping patterns; c) devising alternative agricultural practices, etc.

16. The National Action Plan on Climate Change (2008) has clarified the objectives of implementation through appropriate institutional mechanism, public-private partnerships and civil society action however implementation mechanism has emphatically been institutionalized through related Ministries throughout the $11^{\text {th }}$ and $12^{\text {th }}$ Five-year Plan.

17. Report on Price Policy for Kharif Crops The Marketing Season 2017 - 18, Ministry of Agriculture and Farmers Welfare, Govt. of India, II 1.19, at 33. Available at https://cacp.dacnet.nic.in/ViewReports.aspx?Input=2\&PageId $=39 \&$ KeyId=598 (last visited on Feb. 09, 2019 at 15:40 hr.)

18. Methane - the most effective contributor to climate change and agriculture is considered to be the primary source of methane emissions. Factors like livestock management, management of animal waste, rice cultivation, and crop residue burning, decomposing livestock manure, agroindustrial wastewater, etc. and scientists concluded that using anaerobic digestive technology methane can be captured.

19. Investment of Private Funds with efficient normative rigidity in agro-sector may relieve the financial burden of the State.

20. Green Revolution though increased food production however it perpetuated food insecurity because the wealthy farmers could afford the agrochemicals, fertilizers etc. needed to produce high yields. Again eco-friendly high-end technologically advanced instruments are products of multinational biotechnology corporations. 
21. Supra, 12

22. UN Climate Change Conference, Bonn, November, 2017

23. Ivica Petrikova, (2013) "Bolstering food security through agricultural policies: cross-country evidence", International Journal of Development Issues, Vol. 12 Issue: 2, at 92-109

24. Budgetary allocation to the tune of US\$28.1 billion for micro-irrigation; AGRI-UDAAN for mentoring start-ups to connect with potential investors; Short-term crop loans up to 3 lakh; PMSKY (Pradhan MantriKrishi Sinchai Yojana) for development of irrigation sources; Scheme for Agro-Marine Processing and Development of Agro-Processing Clusters, etc.

25. Available at https://tradingeconomics.com/india/governmentdebt-to-gdp (last visited on Dec. 9, 2017 at 15:53 hours)

26. Source: FAO Statistical Pocketbook World food and agriculture, 2015: ISBN 978-92-5-108802-9 (C) FAO, 2015 available at www.fao.org/publications (last visited on Dec. 09, 2017 at 13:40 hrs)

27. Changing food habits may lead the demand curve upwards. Again increasing food import affects the fiscal policy as well.

28. Cooperative societies - organizations are full of geo-political rivalries and corruption and multiple layers of intermediaries for the creation of a National Market for agricultural commodities.

29. Regulated Markets - the forum that incentivize the individual (including unorganized markets) to pool the excess produce for wholesale assembling.

30. Agricultural Produce Market Committee Act, 2003

31. Minimum Support Price is an insurance mechanism to agricultural producers announced by Government of India as against sharp fall in farm prices during the production years. This has been introduced on the recommendation of the Commission for Agricultural Costs and Prices to protect the producer and farmers.

32. Sec. 31, SARFAESI Act, 2002. In absence of statutory protection of recovery of agricultural loan private participation in agricultural sector of the country would always be considered a challenge, though investment in agricultural sector efficiently and effectively could reduce poverty and promote food security.

33. This would be helpful to customize the amount before advancing the loan amount - one step to assess the risk and risk-mitigating measures.

34. The definition of 'Family' has been elaborated in the Land Reforms Act of every State hence calculation of loan amount and crop- insurance coverage could be ascertained accordingly.

35. For example, credit commitments of INR. 10 Lakh Crores announced in the year 2016for farm sector for helping agroproduce to get better prices and to make agro-sector as a growth driver.

36. The legal mandate as provided under section 27 of the Insurance Act, 1938

37. As practiced in Kenya.

38. As adopted in Tanzania

39. Calvin Miller, Linda Jones, AGRICULTURAL VALUE CHAIN FINANCE: TOOLS AND LESSONS, 2010, FAO and Practical Action, ISBN $9781853397028(\mathrm{~Pb})$ 